\title{
Thrombotic Tendency of Spontaneously Hypertensive Rats Measured by the He-Ne Laser-induced Thrombus Formation Method
}

\author{
Junichiro YAMAMOTO*1, Izumi ISHII*1, Miyuki INOUE*1, \\ Kiyotaka OHTANI*1, Yoko NAGAMATSU*1, Hiroko CHIUE*2 \\ and Takanori KUSANO*2
}

He-Ne レーザー惹起血栓形成法で測定した

自然発症性高血圧ラットの血栓形成傾向

$\begin{array}{llllllll}\text { 山 } & \text { 本 } & \text { 順一郎*1 } & \text { 石 } \text { 井 } & \text { いずみ*1 } & \text { 井 上 } & \text { 幸*1 } \\ \text { 大 } & \text { 谷 } & \text { 清 } & \text { 隆*1 } & \text { 永 松 陽 子*1 } & \text { 地 上 博 子*2 } \\ \text { 草 } & \text { 野 毅 徳*2 } & & & & & & \end{array}$

Key words : prethrombotic state, thrombosis, platelet aggregation, laser, spontaneously hypertensive rat

自然発症性高血圧ラット (SHR) とその対照ラット Wistar Kyoto (WKY) の血栓形成傾向

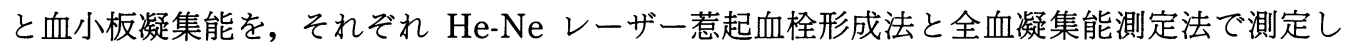
た. 閉塞性血栓形成に要する照射回数は SHR の方が WKY より小さく, 全血凝集能は SHR の方が WKY より妄進を示した. 以上の結果から, SHR の易血栓形成傾向の原因の一つとし て血小板凝集能六進の関与が考えられた.

\begin{abstract}
This experiment measured the thrombotic tendency and platelet aggregability of a spontaneously hypertensive rat (SHR) and its control, Wistar Kyoto (WKY), using the $\mathrm{He}-\mathrm{Ne}$ laser-induced thrombus formation method and the whole blood aggregation method, respectively. The two findings of this required to induce occlusive thrombus formation was smaller in SHR than in WKY and platelet aggregability in SHR was higher than in WKY. These results suggest that higher thrombotic tendency may be partly due to the higher platelet aggregability in SHR.

\footnotetext{
*1 神戸学院大学栄養学部生理学研究室〔651-21 神戸市西区伊川谷町有瀬 518〕：Laboratory of Physiology, Faculty of Nutrition, Kobe-Gakuin University, Nishi-ku, Kobe 651-21, Japan

*2 神戸学院大学栄養学部食品化学研究室: Laboratory of Food Chemistry, Faculty of Nutrition. 受付 : 1990.4.2, 受理 : 1990.8.21.
}

experiment were the number of irradiations 


\section{Introduction}

Thrombus formation has been well known to play an important role in the initiation and development of cerebral and cardiovascular diseases. It is therefore necessary to develop a more practical and useful method of detecting the thrombotic tendency to aid in the prevention and medical treatment of these diseases, although various tests for platelet aggregability and activities of the coagulation and fibrinolytic systems are currently in use $^{1)}$ and various animal models inducing thrombosis experimentally also have been proposed $^{2) \sim 15)}$.

Though there are many factors contributing to thrombosis formation, the platelet thrombus formation is probably the initial event. Therefore, measurement of the tendency to develop platelet thrombus formations is a reasonable approach for determining the thrombotic tendency. The laserinduced thrombus formation method which induces thrombus formation in the microvessels is suitable for the purpose of determining the thrombotic tendency.

It is known that the thrombotic tendency is higher in patients with hypertension as well as in SHR developed by Okamoto and Aoki ${ }^{16)}$ and widely used as an animal model of essential hypertension. The laser-induced thrombus formation method has shown that the thrombotic tendency is higher in SHR than in $W K Y^{17) 18}$. On the other hand, it is also reported that the thrombotic tendency and platelet aggregability are lower in SHR than in WKY ${ }^{19) \sim 21)}$. The aim of the present study is to gain evidence indicating relationship between the thrombotic tendency and platelet aggregability of SHR.

\section{Materials and Methods}

The male SHR and its control rat (WKY) at 10 weeks old were obtained from the Charles River Co. Ltd. (Japan). They were fed with a commercial solid diet (MF, Oriental Yeast Co. Ltd., Japan) and tap water ad libitum.

Experimental microthrombus formation by $\mathrm{He}-\mathrm{Ne}$ laser irradiation

The experiment was performed when the rats were at 25 weeks old. The microthrombus was formed using the method described by Kovacs et al. ${ }^{4) 5}$, with slight modifications. The details are described elsewhere ${ }^{15)}$.

\section{Platelet aggregaion}

Platelet aggregation in whole blood was measured using the impedance method with a Chronolog C-500 aggregometer. Blood was collected from the abdominal aorta into $3.2 \%$ sodium citrate (blood vol. : citrate vol. $=9: 1$ ) immediately after the microthrombus formation experiment, and kept at room temperature for $30 \mathrm{~min}$ until it was used. To $0.5 \mathrm{~m} l$ of Locke solution containing $2 \mathrm{mM} \mathrm{CaCl} 2$ and prewarmed to $37^{\circ} \mathrm{C}, 0.5 \mathrm{~m} l$ of citrated blood was added. The mixture was allowed to stand until the temperature rose to $37^{\circ} \mathrm{C}$ (approximately $4 \mathrm{~min}$ ). Twenty microliters of agonists, i.e. collagen ( $1 \mathrm{mg} / \mathrm{m} l$, Horm), thrombin $(100 \mathrm{u} / \mathrm{ml}$ in $50 \mathrm{mM}$ Tris- $\mathrm{HCl}$ containing $100 \mathrm{mM} \mathrm{NaCl}, \mathrm{pH}$ 7.3, Mochida Pharmaceutical Co. Ltd., Japan) or ADP $(10 \mathrm{mM}$ in $50 \mathrm{mM}$ Tris- $\mathrm{HCl} \mathrm{pH} 6.8$, stored at $-80^{\circ} \mathrm{C}$, Sigma) were added to the mixture and aggregation was recorded for $6 \mathrm{~min}$. The reaction was observed in a plastic cuvette at 1,000 rpm. Collagen-induced platelet aggregation was started $30 \mathrm{~min}$ after the blood was collected, then thrombin- and ADP-induced platelet aggregation tests followed sequentially.

The blood cell count was done using an automatic cell counter (Sysmexmicrocellcounter CC-180A, Toa Medical Electronics Co. Ltd., Japan). 


\section{Blood pressure}

The maximal and mean blood pressure were measured by the tail cuff method with a hemodynamometer (UR-1000, Ueda Seisakusho Co. Ltd., Japan).

\section{Statistics}

Wilcoxon's two-sample test was employed in the analysis of the number of exposures to the laser and platelet aggregation level, unpaired Student's t test for body weight, blood pressure, blood parameters and laser power.

\section{Results}

The growth curve and blood pressure are shown in Figs. 1 and 2, respectively. Though the difference in body weight was not significant at 25 weeks old, the SHR was slightly bigger and its blood pressure was significantly higher than that of WKY.

The number of laser irradiations necessary to induce occlusive thrombus formation in the arterioles and venules of SHR and WKY are shown in Table 1. Significant differences were observed between SHR and WKY showing that SHR has a higher thrombotic tendency than WKY.

Platelet aggregability and blood parameters are shown in Table 2 and $\mathbf{3}$, respectively.

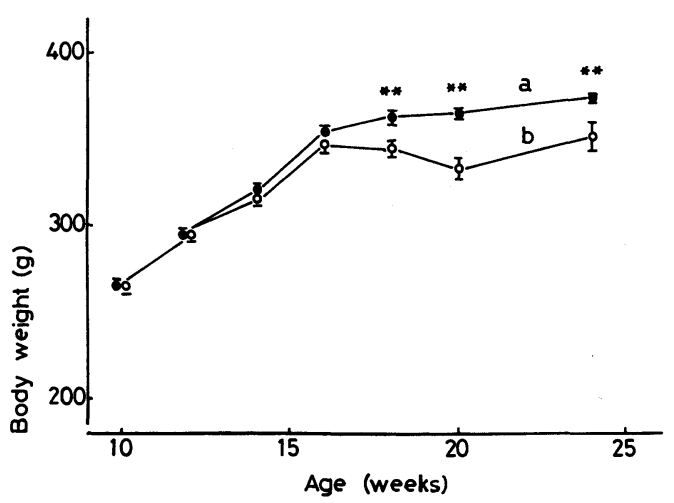

Fig. 1 Growth curve of SHR and WKY

Values are expressed in mean $\pm \mathrm{SE}(\mathrm{n}=20$ in each group).

a : SHR, b : WKY. ${ }^{* *}: \mathrm{P}<0.01$
SHR showed a significantly higher platelet aggregability as well as platelet and erythrocyte counts which were higher than those found in WKY, but differences in leukocyte count and hematocrit were not observed.

\section{Discussion}

Since thrombus formation is induced by the interaction of many factors such as coagulofibrinolytic factors, platelets, erythrocytes, leukocytes, vessel walls and blood flow, it is safe to speculate that a minute and singularly undetectable change in each factor might be detected using the method in which the process of thrombus formation can be observed. The laser-induced thrombus formation method is suitable for this purpose. This ex vivo method can detect a minor change in the thrombotic tendency of physically trained rats at rest, although other tests cannot ${ }^{15}$.

$\mathrm{He}-\mathrm{Ne}$ laser irradiation induces platelet thrombus formation. Fibrin can be rarely seen in this type of thrombus. He-Ne laser irradiation injures and denudes endothelial

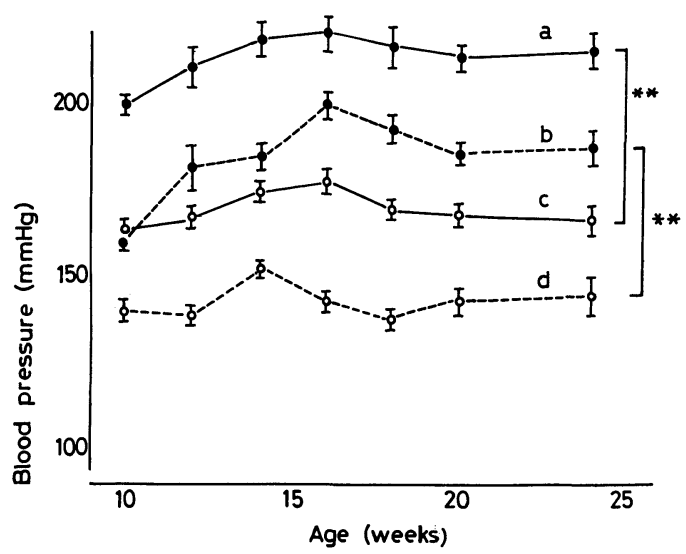

Fig. 2 Change of blood pressure with age Blood pressure of the same subjects shown in Fig. 1 was measured and expressed in mean $\pm \mathrm{SE}$.

$\mathrm{a}$ : maximal blood pressnure of SHR, b : mean blood pressure of SHR, $c$ : maximal blood pressure of WKY, $\mathrm{d}$ : mean blood pressure of WKY. ${ }^{* *}: \mathrm{p}<0.01$ 
Table 1 Laser-induced thrombus formation in SHR and WKY

\begin{tabular}{cccc}
\hline Subject no & Body weight $(\mathrm{g})$ & Arteriole & Venule \\
\hline SHR & & & \\
1 & 390 & 10.7 & 5.0 \\
2 & 380 & 5.5 & 5.0 \\
3 & 380 & 8.0 & 5.0 \\
4 & 380 & 7.0 & 7.5 \\
5 & 360 & 6.0 & 4.3 \\
6 & 350 & 5.5 & 6.5 \\
7 & 370 & 6.0 & 4.3 \\
8 & 380 & 6.0 & 4.0 \\
\hline M \pm SE & $374 \pm 5$ & $6.8 \pm 0.7$ & $5.2 \pm 0.4$ \\
\hline WKY & & & \\
1 & 340 & $\geqq 16$ & 9.0 \\
2 & 340 & 11.3 & 7.0 \\
3 & 420 & 10.0 & 9.5 \\
4 & 360 & $\geqq 16$ & 10.0 \\
5 & 360 & 7.0 & 4.5 \\
6 & 360 & $\geqq 16$ & 10.5 \\
7 & 330 & $\geqq 16$ & 13.0 \\
8 & 380 & 9.0 & 7.5 \\
9 & 360 & 7.0 & 9.0 \\
10 & 310 & $\geqq 16$ & 11.0 \\
\hline M \pm SE & $356 \pm 10$ & $12.4 \pm 1.3$ & $9.1 \pm 0.8$ \\
\hline & ns & $\mathrm{p}<0.01$ & $\mathrm{p}<0.01$ \\
\hline
\end{tabular}

Values in arterioles and venules express the number of laser irradiation necessary to induce occlusive thrombus formation. ns : not significant.

Table 2 Platelet aggregation in SHR and WKY

\begin{tabular}{lccc}
\hline & ADP & collagen & thrombin \\
\hline SHR & $6.0 \pm 0.5$ & $9.0 \pm 0.7$ & $11.8 \pm 2.4$ \\
WKY & $4.0 \pm 0.7$ & $5.5 \pm 0.8$ & $16.0 \pm 1.8$ \\
\hline & $\mathrm{p}<0.05$ & $\mathrm{p}<0.02$ & $\mathrm{~ns}$ \\
\hline
\end{tabular}

Change of the impedance at three minutes after the addition of each agonists ( $\mathrm{ohm} / 3 \mathrm{~min}$ ) is expressed in mean $\pm \mathrm{SE}(\mathrm{n}=8$ in SHR, $\mathrm{n}=10$ in WKY). The final concentrations of $\mathrm{ADP}$, collagen and thrombin were $200 \mu \mathrm{M}, 20 \mu \mathrm{g} / \mathrm{m} l$ and $2 \mathrm{u} / \mathrm{m} l$, respectively. ns : not significant.

cells leading to platelet thrombus formation. But denudation of endothelial cells depends on the power of He-Ne laser and microvessels used ${ }^{522)}$. It is speculated that both of injury and denudation of endothelial cells of microvessels might be occurred by exposure to laser in the present study because of the He-Ne laser power used ${ }^{5)}$. Argon laser irradiation has also been reported to cause damage
Table 3 Blood parameters in SHR and WKY

\begin{tabular}{|c|c|c|c|c|}
\hline & PLT & $\mathrm{RBC}$ & WBC & HCT \\
\hline SHR & $107 \pm 3$ & $1219 \pm 16$ & $50 \pm 6$ & $49.8 \pm 1.0$ \\
\hline \multirow[t]{2}{*}{ WKY } & $67 \pm 6$ & $1112 \pm 25$ & $39 \pm 4$ & $48.6 \pm 1.3$ \\
\hline & $\mathrm{p}<0.01$ & $\mathrm{p}<0.01$ & ns & ns \\
\hline \multicolumn{5}{|c|}{$\begin{array}{l}\text { Values are expressed in mean } \pm \mathrm{SE}(\mathrm{n}=8 \text { in } \\
\mathrm{SHR}, \mathrm{n}=10 \text { in WKY). ns }: \text { not significant. } \\
\mathrm{PLT}: \text { platelet count }\left(\times 10^{4} / \mu l\right), \mathrm{RBC}: \text { eryth- } \\
\text { rocyte count }\left(\times 10^{4} / \mu l\right) \text {, WBC }: \text { leukocyte } \\
\text { count }\left(\times 10^{2} / \mu l\right) \text { and } \mathrm{HCT}: \text { hematocrit }(\%) \text {. }\end{array}$} \\
\hline
\end{tabular}

to endothelial cells followed by platelet thrombus formation ${ }^{8)}$. Biolaser, however, induces the formation of plasma protein precipitates and the destruction of erythrocytes as well as endothelial cells injury leading to platelet thrombus formation ${ }^{23)}$. Fibrin can rarely be seen in Argon- and biolaser-induced thrombus cases ${ }^{823)}$.

The significantly higher thrombotic ten- 
dency of SHR was estimated in the present study. This confirmed the previously reported results employing the laser-induced thrombus formation method ${ }^{17) 18)}$.

On the other hand platelet aggregability was significantly higher in SHR. This differs from results reported previously in which platelet aggregation was measured in platelet rich plasma ${ }^{19) \sim 21)}$. The difference could be explained by the influence of erythrocytes and leukocytes co-existing in whole blood as reported previously ${ }^{24)}$. However, the most dominant factor may be platelet count, because platelet count in SHR was 1.6 times higher than that in WKY. It is speculated that results of platelet aggregations in whole blood may reflect those in the circulatory system.

The higher thrombotic tendency in SHR shown by the He-Ne laser-induced thrombus formation method may be partially due to the higher platelet aggregability. The laserinduced thrombus formation method is a promising method for measurement of the thrombotic tendency in experimental animals.

\section{References}

1) Davis, J.A.: Detection of a prethrombotic state. (Bloom, A.L. and Thomas, D.P.: Haemostasis and Thrombosis), Churchill Livingstone, Edinburgh, London, Melbourne and New York, 1987, $721 \sim 738$

2) Arfors, K.E., Dhall, D.P., Engeset, J., Hint, H., Matheson, N. and Tangen, O.: Biolaser endothelial trauma as a means of quantifying platelet activity in vivo. Nature, 218: 887 888, 1968.

3) Begent, N. and Born, G.V.R.: Growth rate in vivo of platelet thrombi, produced by iontophoresis of ADP, as a function of mean blood flow velocity. Nature, 227 : 926 930, 1970.

4) Kovacs, I.B., Caslay, L. and Gorog, P.: Laserinduced microvascular thrombosis in the mi- crocirculation of hamster cheek pouch and its inhibition by acetylsalicylic acid. Microvasc. Res., 6 : 194 201, 1973.

5) Kovacs I.B., Tigyi-Sebes, A., Trombitas, K. and Gorog, P.: Evans blue: an ideal energyabsorbing material to produce intravascular microinjury by the He-Ne gas laser. Microvasc. Res., 10 : 107 124, 1975.

6) Shishido, M. and Katori, M.: A quantitative method using continuous recording of platelet thrombus size in hamster cheek pouch. Microvasc. Res., 22 : 199 209, 1981.

7) Sato, M. and Ohshima, N.: Platelet thrombus induced in vivo by filtered light and fluorescent dye in mesenteric microvessels of the rat. Thromb. Res., 35 : 319 334, 1984.

8) Weichert, W., Breddin, H.K. and Staubesand, J. : Application of a laser-induced endothelial injury model in the screening of antithrombotic drugs. Sem. Thromb. Haemost. Suppl., 14: 106 114, 1988.

9) Hladovec, J.: A quantitative model of venous stasis thrombosis in rats. Physiologia Bohemoslovaca, 24 : 551 554, 1975.

10) Reyers, I., Mussoni, L., Donati, M.B. and de Gaetano, G. : Failure of aspirin at different dose to modify experimental thrombosis in rats. Thromb. Res., 18: 669 674, 1980

11) Kumada, T., Ishihara, M., Ogawa, H. and Abiko, Y. : Experimental model of venous thrombosis in rats and effect of some agents. Thromb. Res., 18 : 189 203, 1980.

12) Dejana, E., Villa, S. and de Gaetano, G. : Bleeding time in rats: a comparison of different experimental conditions. Thromb. Haemostasis, 48 : 108 111, 1982.

13) Millet, J., Theveniaux, J. and Pascal, M. : A new experimental model of venous thrombosis in rats involving partial stasis and slight endothelium alterations. Thromb. Res., 45 : 123 133, 1987.

14) Walenga, J.M., Petitou, M., Lormeau, J.C., Samama, M., Fareed, J. and Choay, J.: Antithrombotic activity of a synthetic heparin pentasaccharide in a rabbit stasis thrombosis model using different thrombogenic challenges. 
Thromb. Res., 46 : 187 198, 1987.

15) Yamatomo, J., Iizumi, H., Hirota, R., Shimonaka, K., Nagamatsu, Y., Horie, N. and Morita, S. : Effect of physical training on thrombotic tendency in rats: decrease in thrombotic tendency measured by the He-Ne laser-induced thrombus formation method. Haemostasis, 19: 260 265, 1989.

16) Okamoto, K. and Aoki, K.: Development of a strain of spontaneously hypertensive rats. Jap. Circl. J., 27 : 282 293, 1963.

17) Gorog, P. and Kovacs, I.B. : Laser-induced thrombus formation and vascular reactivity in the microcirculation of the spontaneously hypertensive rat. Blood Vessels, 14 : 294 302, 1977.

18) Seiffge, D. and Weithman, K.U.: Surprising effects of the sequential administration of pentoxiphylline and low dose acetylsalicylic acid on thrombus formation. Thromb. Res., 46: 371 $\sim 383,1987$.

19) Nagaoka, A., Sudo, K., Orita, S., Kikuchi, K. and Aramaki, Y. : Hematological studies on the spontaneously hypertensive rats with special referece to the development of thrombosis. J. Circl. J., 35 : 1379 1390, 1971.
20) Yamori, Y., Ohta, K., Horie, R., Ohtaka, M., Nara, Y. and Ooshima, A.: A new model for cerebral thrombosis and its pathogenesis. Jap. Heart J., 20 (Suppl. 1) : 343 345, 1979.

21) Mashimo, N., Sunaga, T., Matsubara, O., Kikutani, N., Motomiya, T. and Yamazaki, H. : Platelet hypoaggregability and decrease in thrombogenic tendency in SHR. Jap. Heart J. 20 (Suppl. 1) : 362 364, 1979.

22) Povlishock, J.T. and Rosenblum, W.I. : Injury of brain microvessels with a helium- neon laser and Evans blue can elicit local platelet aggregation without endothelial denudation. Arch. Pathol. Lab. Med. III : 415 421, 1987.

23) Hovig, T., Mckenzie, F.N. and Arfors, K.-E. : Measurement of the platelet response to laserinduced microvascular injury. Ultrastructural studies. Thrombos. Diathes. Haemorrh., 32 : 695 $\sim 703,1974$.

24) Joseph, R. Welch, K.M.A., D'Andrea, G. and Riddle, J.M. : Evidence for the presence of red and white blood cells within "platelet" aggregates formed in whole-blood. Thromb. Res., 53 : 485〜491, 1989. 